\title{
ФОРМУВАННЯ СТРАТЕГІЧНИХ ПРІОРИТЕТІВ СТАЛОГО РОЗВИТКУ ТУРИСТИЧНО-РЕКРЕАЦИЙНОЇ СФЕРИ НА ЗАСАДАХ ІНКЛЮЗИВНОГО ЗРОСТАННЯ
}

\author{
Східноєвропейський національний університет імені Лесі Украйнки
}

Розкрито зміст та економічну роль туристично-рекреаційної сфери. Висвітлено особливості іiі розвитку в Україні, охарактеризовано причини, що гальмують цей процес. Враховуючи зростаюче значення збереження природних ресурсів для сектору подорожей, туризму, відпочинку, оздоровлення доведено необхідність здійснення туристично-рекреаційної діяльності на засадах сталого розвитку та інклюзивного зростання.

Визначено, що сталий розвиток туристично-рекреаційної сфери на засадах інклюзивного зростання передбачає залучення усіх верств населення (у тому числі малозабезпечених, жінок, осіб 3 обмеженими фізичними можливостями, ін. ) до виробничо-господарської, управлінської туристичної та рекреаційної діяльності як працівників, споживачів послуг, посередників, інвесторів, постачальників ресурсів, партнерів на всіх етапах ланцюга створення доданої вартості.

Обгрунтовано, що напрями, які визначені у Стратегії розвитку туризму та курортів на період до 2026 року, складено відповідно до вимог та проблем розвитку туристично-рекреаційної сфери в Україні. 3 огляду на пріоритети сталого розвитку та орієнтацію на досягнення нової якості економічного зростання на основі базових принципів інклюзивного розвитку, вони потребують конкретизації та розширення. Розкрито поняття інклюзивного туризму та інклюзивної рекреації, що характеризують розширення можливостей використання та вільний доступ до туристичних і рекреаційних послуг осіб з обмеженими фізичними можливостями. Запропоновано інтерпретацію відношення глобальних Цілей сталого розвитку до туристично-рекреаційної сфери України. Реалізація стратегічних пріоритетів сталого розвитку туристично-рекреаційної сфери на засадах інклюзивного зростання дозволить виявити можливості для забезпечення рівного доступу до ринків туристично-рекреаційних послуг, використання туристичнорекреаційних ресурсів.

Ключові слова: туристично-рекреаційна сфера, сталий розвиток, інклюзивне зростання, Глобальні изілі сталого розвитку, стратегічні пріоритети, інклюзивний туризм, інклюзивна рекреація.

\section{FORMATION OF STRATEGIC PRIORITIES FOR SUSTAINABLE DEVELOPMENT OF TOURISM AND RECREATION SPHERE BASED ON INCLUSIVE GROWTH}

\author{
Lesya Ukrainka Eastern European National University
}

\begin{abstract}
The content and economic role of the tourist and recreational sphere are revealed. The peculiarities of its development in Ukraine are highlighted; the reasons that inhibit this process are described. Given the growing importance of preserving natural resources for the travel sector, tourism, recreation, health, the need for tourism and recreational activities based on sustainable development and inclusive growth has been proven.

It is determined that the sustainable development of the tourist and recreational sphere based on inclusive growth involves all segments of the population (including the poor, women, people with disabilities, etc.) in industrial, economic, tourist and recreational activities as workers, consumers, intermediaries, investors, resource suppliers, partners at all stages of the value chain.

It is substantiated that the directions defined in the Strategy of tourism and resorts development for the period till 2026, are made according to requirements and problems of tourist and recreational sphere development in Ukraine. Given the priorities of sustainable development and the focus on achieving a new quality of economic growth based on the basic principles of inclusive development, they need to be concretized and expanded. The concepts of inclusive tourism and inclusive recreation are characterized, which defined as the expansion of opportunities for use and free access to tourist and recreational services for people with disabilities.

The interpretation of the correlation of the global Sustainable Development Goals to the tourist and recreational sphere of Ukraine is offered. Implementation of strategic priorities for sustainable development of the tourist and recreational sphere based on inclusive growth will identify opportunities to ensure equal access to the markets of tourist and recreational services, the use of tourist and recreational resources.
\end{abstract}


Key words: tourist and recreational sphere, sustainable development, inclusive growth, Sustainable Development Goals, strategic priorities, inclusive tourism, inclusive recreation.

Постановка проблеми у загальному вигляді i ï̈ зв'язок з важливими науковими та практичними завданнями. Туристично-рекреаційна сфера $\epsilon$ привабливим видом економічної діяльності, яка у всьому світі приносить високі та стабільні прибутки. Вона є важливим чинником стабільного й динамічного збільшення надходжень до державного бюджету, а також $є$ імпульсом для розвитку багатьох галузей економіки [1]. Згідно із статистичними даними економічно розвинутих країн, міжнародний туризм вважається одним із найприбутковіших видів суб'єктів господарювання, що є вагомим стимулом для розвитку культурного та відпочинкового туризму в Україні [2].

Позитивна динаміка розвитку ринку туристично-рекреаційних послуг, привабливість туристично-рекреаційних продуктів, зростання попиту на них, соціальноекономічна ефективність туристично-рекреаційного бізнесу обумовлюють необхідність формування стратегічних пріоритетів розвитку туристично-рекреаційної сфери із врахуванням Цілей сталого розвитку та орієнтацією щодо досягнення нової якості економічного зростання на основі базових принципів інклюзивного розвитку.

Аналіз останніх досліджень, у яких започатковано вирішення проблеми. Аналіз підходів вітчизняних і зарубіжних науковців до трактування понять «туризм» $\mathrm{i}$ «рекреація» дозволив зробити висновок про «необхідність їх комплексного сприйняття, як єдиної сфери, мета котрої полягає у відновленні та розвитку життєвих сил людини» [3, С.6]. Туристична та рекреаційна діяльності є видами господарської діяльності 3 організації туризму, екскурсій, дозвілля, відпочинку, курортно-профілактичного лікування, оздоровлення.

У науковій літературі домінує диференційований підхід до визначення туристичної та рекреаційної діяльності. Пропонуємо туристично-рекреаційну сферу визначати як цілісний напрям діяльності з надання туристично-рекреаційних послуг, що «зорієнтований на відновлення фізичних і психічних сил населення, його духовне та культурне збагачення» [4, с. 33].

Дослідження проблеми формування пріоритетів і механізмів реалізації стратегії розвитку туризму та рекреації здійснили у свої працях такі вчені, як І. Балобанов, М. Гусєвої, М. Долішній, В. Євдокименко, В. Кравців, О. Лютак, М. Мальська, В. Павлов, С. Харічков, І. Школа та інші. Незважаючи на достатній методологічний базис існуючих розробок, проблематика формування і запровадження концептуальних стратегічних пріоритетів сталого розвитку туристично-рекреаційної сфери на засадах інклюзивного зростання потребує постійного удосконалення.

Цілі статті. Метою статті є обгрунтування необхідності здійснення туристичнорекреаційної діяльності на засадах сталого розвитку та інклюзивного зростання та формування стратегічних пріоритетів сталого розвитку туристично-рекреаційної сфери України у взаємоузгодженні з глобальними Цілями сталого розвитку.

Виклад основного матеріалу дослідження 3 повним обгрунтуванням отриманих наукових результатів. Слід зазначити, що туристично-рекреаційний потенціал в Україні використовується не раціонально та не у повній мірі. Про це свідчить незначний внесок туристичної сфери у загальний обсяг виробленої продукції за усіма видами діяльності в Україні, що не перевищує й одного відсотка (таблиця 1).

У 2018 році частка надходжень від туризму у загальному експорті в Україні становила $3,8 \%$ (рисунок 1). Особливо негативно відобразився на динаміці показників політичний конфлікт, який розпочався у 2013 р. На сьогодні частка туризму у структурі експорту в України є значно нижчою, в порівнянні із низкою розвинутих країн Європи, водночас дещо перевищує показники Німеччини, де питома вага від туристичної діяльності протягом усього періоду коливалась в межах 3,17-3,4 та у 2018 р. склала 3,21 $\%$. 
На розвиток туристично-рекреаційної сфери впливають інвестиції у готельну та ресторанну сферу, частка яких поступово зростає. Не дивлячись на це, об'єкти туристично-рекреаційної інфраструктури в країні розвинуті недостатньо, є морально зношеними.

Таблиця 1

Економічна роль туристичної сфери

\begin{tabular}{|c|c|c|c|c|c|c|}
\hline \multirow{3}{*}{ Роки } & \multirow{2}{*}{\multicolumn{2}{|c|}{$\begin{array}{l}\text { Обсяг реалізованої продукції } \\
\text { (товарів, послуг) }\end{array}$}} & \multicolumn{4}{|c|}{$\begin{array}{c}\text { Діяльність туристичних агентств, туристичних } \\
\text { операторів, надання інших послуг із бронювання та пов'язана } 3 \\
\text { цим діяльність }\end{array}$} \\
\hline & & & \multicolumn{2}{|c|}{$\begin{array}{c}\text { Обсяг реалізованої } \\
\text { продукції за видами економічної } \\
\text { діяльності млн. грн. }\end{array}$} & \multicolumn{2}{|c|}{$\begin{array}{l}\text { Частка у загальному } \\
\text { обсязі виробленої продукції в } \\
\text { Україні, \% }\end{array}$} \\
\hline & усього & $\begin{array}{l}\text { фізичних осіб- } \\
\text { підприємців } \\
\end{array}$ & усього & $\begin{array}{l}\text { фізичних осіб- } \\
\text { підприємців } \\
\end{array}$ & усього & $\begin{array}{l}\text { фізичних осіб- } \\
\text { підприємців } \\
\end{array}$ \\
\hline 2010 & 3692554,5 & 230418,2 & 4703,7 & 198,8 & 0,13 & 0,09 \\
\hline 2011 & 4302627,2 & 211215,8 & 4888,6 & 154,6 & 0,11 & 0,07 \\
\hline 2012 & 4563794,8 & 256649,2 & 6080,7 & 625,8 & 0,13 & 0,24 \\
\hline 2013 & 4437326,1 & 284238,1 & 6269,9 & 742,5 & 0,14 & 0,26 \\
\hline 2014 & 4608978,1 & 289042,3 & 4509,1 & 634,8 & 0,10 & 0,22 \\
\hline 2015 & 5716431,0 & 397473,3 & 5519,8 & 909,1 & 0,10 & 0,23 \\
\hline 2016 & 6877077,4 & 489204,6 & 7006,8 & 1303,5 & 0,10 & 0,27 \\
\hline 2017 & 8467032,0 & 604336,7 & 8434,5 & 1706,7 & 0,10 & 0,28 \\
\hline 2018 & 10148847,2 & 760755,1 & 11873,9 & 2407,0 & 0,12 & 0,32 \\
\hline
\end{tabular}

Джерело: розраховано автором

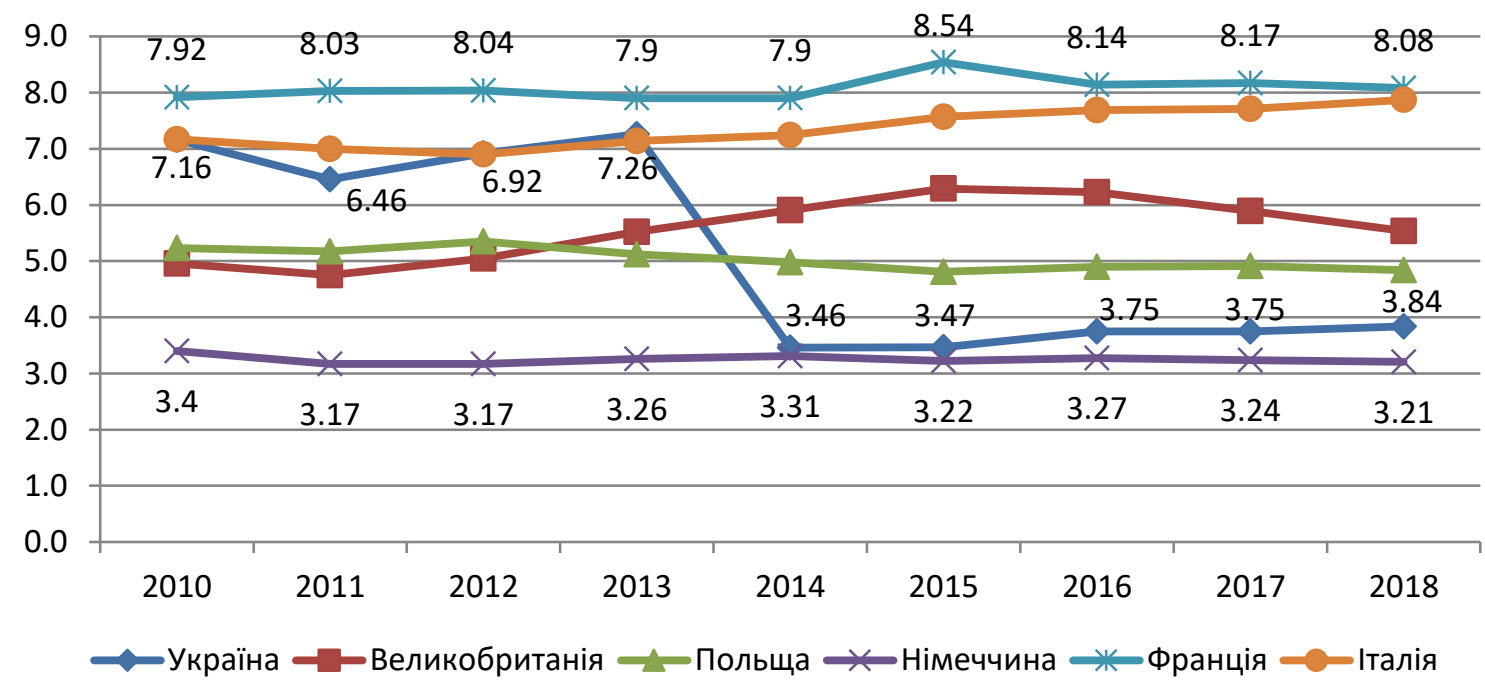

Рис. 1. Частка надходжень від туристичної сфери у загальному експорті, \% Джерело: побудовано автором

Серед основних причин, що стримують розвиток туристично-рекреаційної сфери в Україні, та обумовлюють зменшення в'їзного туристичного потоку, є: події, пов'язані 3 анексією Автономної Республіки Крим та повномасштабною війною на території Донецької та Луганської областей; недостатньо розвинута туристична та рекреаційна інфраструктура; фінансово-економічна криза, що загострилася останніми роками; втрата популярності туристичного напрямку; відсутність ефективної політики щодо 
просування туристичних та рекреаційних продуктів i туристичних напрямків; неефективна організація, управління туристичною і рекреаційною діяльністю; дефіцит якісного традиційного продукту.

На нашу думку, розвиток туристично-рекреаційної сфери повинен відповідати орієнтирам сталого та інклюзивного зростання. Так, згідно трактуванням Світової Організації Туризму, сталий розвиток туристичної сфери полягає у врахуванні його поточних та майбутніх економічних, соціальних та екологічних наслідків її діяльності, задовольняючи зростаючі потреби туристів, галузі, довкілля, громади [5]. 3 огляду на зростаюче значення раціонального використання, охорони та відтворення природних ресурсів для сектору подорожей, туризму, відпочинку, оздоровлення, звернемо увагу на необхідність здійснення туристично-рекреаційної діяльності на засадах сталого розвитку та інклюзивного зростання.

Споживачі туристично-рекреаційних послуг вимагають більш відповідального сервісу і якісного туристично-рекреаційного продукту, у зв'язку з цим діяльність, як державного, так i приватного секторів у туристично-рекреаційній сфері мають здійснюватися відповідно до цілей сталого розвитку [6].

У доповнення до традиційних моделей економічного розвитку, таким, як нульового зростання, сталого розвитку, ноосферного розвитку, інноваційного зростання розроблено концепцію інклюзивного зростання.

Звернемо увагу, що змістовні характеристики інклюзивного туризму, інклюзивної рекреації, інклюзивного розвитку, інклюзивного зростання відрізняється між собою.

На відміну від інших концептуальних поглядів на розширення економічних можливостей і рівного доступу усіх верств населення, «інклюзивне зростання - це концепція, яка забезпечує справедливі можливості та рівноправ'я для економічних учасників, що супроводжується вигодами, принесеними кожному сектору економіки та різним верствам суспільства. Даний підхід розширює традиційні моделі економічного зростання та включає зосередження уваги на рівності здоров'я, людського капіталу, екологічного стану довкілля, соціального захисту та продовольчої безпеки як чинників світової безпеки в широкому розумінні» [7]. Інклюзивне зростання як самостійна концепція зосереджена навколо взаємодії зазначених вище економічних категорій економічного зростання, бідності, нерівності доходів і можливостей.

Інклюзивне зростання представляє собою «зростання, що не лише створює нові економічні можливості, а й забезпечує рівний доступ до них для всіх верств населення, особливо для уразливих його представників» [8]. Виходячи з цього, формуються поняття інклюзивного туризму та інклюзивної рекреації, що характеризують розширення можливостей використання та вільний доступ до туристичних і рекреаційних послуг осіб 3 обмеженими фізичними можливостями.

Цілі інклюзивного розвитку в Свропейському Союзі є стратегічним пріоритетом програми «Свропа - 2020», де зазначається, що «зростання має бути інтелектуальним, стійким і інклюзивним при залученні до відповідних процесів усіх секторів економіки, усіх верств суспільства для досягнення високого рівня зайнятості, продуктивності i соціальної єдності» [9]. Поняття інклюзивного розвитку має широке значення, i стосується усіх сфер людської діяльності, у тому числі і туристично-рекреаційної сфери.

Становлення поняття «інклюзивний розвиток туристично-рекреаційної сфери» відбувається у процесі конкретизації теоретичних концепцій сталого розвитку туристичних та рекреаційних підприємств, бізнес-моделей їх розвитку. Сталий розвиток туристично-рекреаційної сфери на засадах інклюзивного зростання передбачає залучення усіх верств населення (у тому числі малозабезпечених, у яких середньомісячний сукупний дохід нижчий від прожиткового мінімуму, жінок, осіб 3 обмеженими фізичними можливостями, ін. ) до виробничо-господарської, управлінської туристичної та рекреаційної діяльності як працівників, споживачів послуг, посередників, інвесторів, постачальників ресурсів, партнерів на всіх етапах ланцюга створення доданої вартості, формуючи та управляючи вартість один одного. Відповідно до цього 
працівники, споживачі послуг, посередники, інвестори, постачальники ресурсів, партнери виступають учасниками інклюзивного розвитку підприємств туристичнорекреаційної сфери.

Інституційні засади процесу сталого розвитку туристично-рекреаційної сфери в Україні знайшли відображення у низці законодавчих та програмних документів, на які потрібно спиратися практично, а саме: Закони України «Про туризм», «Про курорти»; Постанови Верховної Ради України «Про підсумки парламентських слухань про стан та перспективи розвитку туризму в Україні»; Укази Президента України «Про день туризму», «Про Основні напрями розвитку туризму в Україні до 2020 року», «Про заходи щодо забезпечення реалізації державної політики у галузі туризму», «Про деякі заходи щодо розвитку туристичної та курортно-рекреаційної сфер України»; «Про затвердження Державної програми розвитку туризму», «Про затвердження Порядку організації виїзду дітей за кордон на відпочинок та оздоровлення», «Про затвердження Положення про Державну службу туризму і курортів»; Розпорядження Кабінету Міністрів України «Про схвалення Стратегії розвитку туризму та курортів на період до 2026 року», «Про схвалення концепції Державної цільової програми розвитку туризму та курортів на період до 2022 року» та ін.

Стратегічними пріоритетами розвитку туристично-рекреаційної сфери в Україні визначено «заощадливе та раціональне відношення до об'єктів культурної спадщини на місцевому рівні для здійснення туристичної та рекреаційної діяльності; розроблення i затвердження Державної цільової програми розвитку туризму і курортів України на період до 2022 року; розвиток сталого туризму, зеленого туризму у сільській місцевості; створення якісного та диверсифікованого туристичного продукту на основі раціонального використання наявних на місцевому рівні туристичних та рекреаційних ресурсів; створення в Україні туристично-рекреаційних кластерів; формування позитивного іміджу України (створення бренду - «Туристична Україна») у сфері туризму на зовнішньому та внутрішньому туристичному ринку; створення в Україні загальнодержавної інформаційної мережі у сфері туризму та курортів (рекреації), зокрема шляхом розвитку мережі спеціалізованих інформаційних центрів (що будуть спеціалізуватися на оприлюдненні інформації щодо об'єктів туризму та рекреації) на всій території України» [10].

Стратегічним планом діяльності Міністерства розвитку економіки, торгівлі та сільського господарства України на 2017-2024 роки задля забезпечення конкурентоспроможності економіки України як основи для стійкого економічного зростання та підвищення стандартів і якості життя населення передбачено формування основних засад розвитку сталого туризму та курортів як пріоритетної галузі економіки країни.

Стратегію розвитку туризму та курортів на період до 2026 року складено відповідно до вимог та проблем розвитку туристично-рекреаційної сфери в Україні. У документі головною метою визначено «формування сприятливих умов для активізації розвитку сфери туризму та курортів згідно з міжнародними стандартами якості та 3 урахуванням європейських цінностей, перетворення іiі на високорентабельну, інтегровану у світовий ринок конкурентоспроможну сферу, що забезпечує прискорення соціально-економічного розвитку регіонів і держави в цілому, сприяє підвищенню якості життя населення, гармонійному розвитку і консолідації суспільства, популяризації України у світі» [11].

Дорожня карта Стратегії розвитку туризму та курортів на період до 2026 року є розписаною за такими напрямами, як «Безпека туристів», «Нормативно-правова база сфери туризму та курортів», «Розвиток туристичної інфраструктури», «Розвиток людських ресурсів», «Маркетингова політика розвитку туризму та курортів України». Вважаємо, що спектр цих напрямів, 3 огляду на пріоритети сталого розвитку та орієнтацію на досягнення нової якості економічного зростання на основі базових 
принципів інклюзивного розвитку, втілених у Цілях сталого розвитку, потребує розширення.

Отже, стратегічні пріоритети сталого розвитку туристично-рекреаційної сфери України мають узгоджуватися 3 глобальними рішеннями, які прийняті світовою спільнотою - глобальними Цілями сталого розвитку, затвердженими у 2015 році на саміті ООН з питань сталого розвитку, та відповідати Національній доповіді від 15 вересня 2017 року «Цілі сталого розвитку: Україна» (таблиця 2).

Таблиця 2

Інтерпретація відношення глобальних Цілей сталого розвитку до туристичнорекреаційної сфери України

\begin{tabular}{|c|c|}
\hline Ціль сталого розвитку & Пріоритетність для туристично-рекреаційної сфери України \\
\hline Ціль 1 «ні бідності» & $\begin{array}{c}\text { Збільшення доходів від туристично-рекреаційної діяльності; залучення } \\
\text { інвестицій; розширення можливості населення щодо працевлаштування та } \\
\text { самозайнятості }\end{array}$ \\
\hline Ціль 2 «Ні голоду» & $\begin{array}{c}\text { Підвищення зайнятості населення, створення робочих місць, розвиток аграрного } \\
\text { туризму }\end{array}$ \\
\hline Ціль 3 «Гарне здоров'я» & Розширення і покращення суспільних послуг оздоровлення і відпочинку \\
\hline Ціль 4 «Якісна освіта» & $\begin{array}{c}\text { Розширення можливостей кар’єрного зростання у туристично-рекреаційному } \\
\text { бізнесі; організація системи якісної підготовки, перепідготовки та підвищення } \\
\text { кваліфікації фахівців туристичного супроводу та обслуговування, інших } \\
\text { професій туристично-рекреаційної сфери; міжкультурний обмін, розвиток } \\
\text { місцевої культури }\end{array}$ \\
\hline Ціль 5 «Гендерна рівність» & Пріоритет розвитку усіх напрямків діяльності туристично-рекреаційної сфери \\
\hline $\begin{array}{c}\text { Ціль } 6 \text { «Чиста вода та належні } \\
\text { санітарні умови» }\end{array}$ & $\begin{array}{l}\text { Забезпечення раціонального використання водних ресурсів, охорона водних } \\
\text { об’єктів; дотримання санітарно-гігієнічних норм у туристично-рекреаційній } \\
\text { діяльності }\end{array}$ \\
\hline $\begin{array}{c}\text { Ціль } 7 \text { «Відновлювальна } \\
\text { енергія» }\end{array}$ & Використання енергоощадних технологій, альтернативних джерел енергії \\
\hline $\begin{array}{l}\text { Ціль } 8 \text { «Гідна праця та } \\
\text { економічне зростання» }\end{array}$ & $\begin{array}{l}\text { Розвиток рекреації та оздоровлення як факторів забезпечення гідної праці; } \\
\text { підвищення ефективності використання туристично-рекреаційних ресурсів, } \\
\text { мультиплікативний вплив туристично-рекреаційної діяльності на економіку }\end{array}$ \\
\hline $\begin{array}{l}\text { Ціль } 9 \text { «нновації та } \\
\text { інфраструктура» }\end{array}$ & $\begin{array}{c}\text { Інноваційний розвиток туристично-рекреаційної сфери; розвиток туристичної } \\
\text { інфраструктури; доступність туристично-рекреаційних послуг }\end{array}$ \\
\hline $\begin{array}{l}\text { Ціль } 10 \ll \text { «меншення } \\
\text { нерівності» }\end{array}$ & $\begin{array}{c}\text { Рівність можливостей для діяльності у туристично-рекреаційній сфері; } \\
\text { забезпечення доступності об’єктів туристичної інфраструктури і рекреації для } \\
\text { осіб з інвалідністю та інших маломобільних груп населення } \\
\end{array}$ \\
\hline $\begin{array}{c}\text { Ціль } 11 \text { «Сталий розвиток } \\
\text { міст та спільнот» }\end{array}$ & $\begin{array}{c}\text { Розвиток міст як туристичних лідерів на засадах розумного зростання, } \\
\text { залучення місцевого населення до розширення туристично-рекреаційних послуг }\end{array}$ \\
\hline $\begin{array}{l}\text { Ціль } 12 \text { «Відповідальне } \\
\text { споживання» }\end{array}$ & $\begin{array}{c}\text { Сприяння впровадженню технологій ощадного споживання у туристично- } \\
\text { рекреаційній діяльності }\end{array}$ \\
\hline $\begin{array}{c}\text { Ціль } 13 \text { «Боротьба зі зміною } \\
\text { клімату» }\end{array}$ & $\begin{array}{c}\text { Охорона, відтворення та раціональне використання природних туристично- } \\
\text { рекреаційних продуктів }\end{array}$ \\
\hline $\begin{array}{l}\text { Ціль } 14 \text { «Збереження } \\
\text { морських екосистем» }\end{array}$ & $\begin{array}{c}\text { Збереження природи, екосистемний підхід у морському туризмі та } \\
\text { рекреаційній діяльності }\end{array}$ \\
\hline $\begin{array}{l}\text { Ціль } 15 \text { «Збереження } \\
\text { екосистем суші» }\end{array}$ & $\begin{array}{c}\text { Забезпечення збалансованого використання природних лікувальних та } \\
\text { рекреаційних ресурсів, збереження здатності природних комплексів до } \\
\text { самовідтворення, запровадження оплатних екосистемних послуг у рекреаційно- } \\
\text { туристичній сфері }\end{array}$ \\
\hline $\begin{array}{l}\text { Ціль } 16 \text { «Мир та } \\
\text { справедливість» }\end{array}$ & $\begin{array}{c}\text { Забезпечення безпеки туристів і рекреантів та захист їх законних прав та } \\
\text { інтересів }\end{array}$ \\
\hline $\begin{array}{l}\text { Ціль } 17 \text { «Партнерство за ради } \\
\text { стійкого розвитку» }\end{array}$ & $\begin{array}{c}\text { Розвиток державно-приватного партнерства, розвиток міжнародної співпраці у } \\
\text { туристично-рекреаційній діяльност; розширення зв’язків з міжнародними, } \\
\text { регіональними та національними туристичними асоціаціями }\end{array}$ \\
\hline
\end{tabular}
Джерело: розроблено автором з використанням [12-15].

Висновки. Реалізація стратегічних пріоритетів сталого розвитку туристичнорекреаційної сфери на засадах інклюзивного зростання дозволить виявити можливості для забезпечення рівного доступу до ринків туристично-рекреаційних послуг, туристично-рекреаційних ресурсів і неупередженого регуляторного середовища для 
різних соціальних груп, формування механізмів забезпечення продуктивної зайнятості, збільшення доходів для відчужених груп і подолання бідності, вироблення нових підходів до споживання обмежених ресурсів і досягнення інклюзивного зростання у довгостроковій перспективі.

\section{Список бібліографічного опису}

1. Грабовенська С. П. Аналіз і структура ринку туристичних послуг в Україні. Науковий вісник Полтавського університету економіки $i$ торгівлі. Серія: Економічні науки. 2013. № 1. С. 226-234. URL: http://nbuv.gov.ua/UJRN/Nvpusk_2013_1_48

2. Маковей Ю. П. Розвиток сфери туризму в Україні. Ефективність держсавного управління. 2015. Вип. 44 (2). С. $87-$ 93. URL: http://nbuv.gov.ua/UJRN/efdu_2015_44\%282\%29_13

3. Котенко Т. М. Соціальний вимір розвитку рекреації та туризму: автореф. дис. ... канд. екон. наук: 08.00 .07 / Ін-т демографії та соц. досліджень ім. М. В. Птухи НАН України. Київ, 2016. 20 с.

4. Новикова В. І. Рекреаційні послуги: класифікація та розвиток у Черкаській області. Український географічний журнал. 2009. № 4. С. 33-39.

5. Sustainable Development. World Tourism Organization. URL: https://www.unwto.org/ru/node/79

6. Planning For Sustainable \& Inclusive Growth. World Travel \& Tourism Council. URL: https://wttc.org/Research/Insights/moduleId/1053/itemId/34/controller/DownloadRequest/action/QuickDownload

7. Ranieri R., Ramos R. A. Inclusive Growth: Building up a Concept. International Policy Centre for Inclusive Growth. Working Paper. Brazil. 2013. no 104. URL: https://ipcig.org/pub/IPCWorkingPaper104.pdf

8. Цимбалюк I. О. Інклюзивний розвиток регіону в умовах фінансової децентралізації: теорія, методологія, практика: монографія. Луцьк: Вежа-Друк, 2019. 340 с.

9. Europe 2020. A European strategy for smart, sustainable and inclusive growth. European Commission. Brussels, 2010. 34 p. URL: http://ec.eu-ropa.eu/europe2020/index_en.htm

10. Біла С. О. Стратегічні пріоритети розвитку туристичних послуг в Україні та перспективи підвищення іх конкурентоспроможності на світовому ринку. Стратегія розвитку України. 2016. № 1. С. 17-23. URL: http://nbuv.gov.ua/UJRN/sru_2016_1_5

11. Про схвалення Стратегії розвитку туризму та курортів на період до 2026 року: Розпорядження Кабінету Міністрів України від 16.03.2017 p. № 168-p. URL: https://zakon.rada.gov.ua/ laws/show/168-2017-\%D1\%80

12. Ковальова О.В. Концептуальні стратегічні пріоритети розроблення структурної політики сталого розвитку аграрного сектору економіки: національний і регіональний аспекти. Вісник Черкаського університету. 2019 . № 2. C. 66-76.

13. Павліха Н. В., Скороход І. С. Екологізація туристичної сфери: інноваційний підхід. Вісник ДІТБ. 2005. № 9. С. 185189.

14. Khomiuk N., Pavlikha N. Economic security of development of rural territories in Ukraine. International Journal of New Economics and Social Sciences. 2018. № 1 (7). P. 119-130.

15. Хомюк Н. Л. Диверсифікація розвитку сільських територій в умовах децентралізації: монографія. Луцьк: ВежаДрук, 2019. 320 с.

\section{References:}

1. Hrabovenska, S. P. (2013). Analiz i struktura rynku turystychnykh posluh v Ukraini [Analysis and structure of the market of tourist services in Ukraine]. Naukovyi visnyk Poltavskoho universytetu ekonomiky i torhivli. Seriia: Ekonomichni nauky. Scientific Bulletin of Poltava University of Economics and Trade. Series: Economic Sciences, 1. 226-234. Retrieved from http://nbuv.gov.ua/UJRN/Nvpusk_2013_1_48 [in Ukrainian].

2. Makovei, Yu. P. (2015). Rozvytok sfery turyzmu v Ukraini [Development of tourism in Ukraine]. Efektyvnist derzhavnoho upravlinnia - Efficiency of public administration, 44 (2). 87-93. Retrieved from http://nbuv.gov.ua/UJRN/efdu_2015_44\%282\%29_13 [in Ukrainian].

3. Kotenko, T. M. (2016). Sotsialnyi vymir rozvytku rekreatsii ta turyzmu [Social dimension of recreation and tourism development].Extended abstract of candidate's of tesis. Kyiv [in Ukrainian].

4. Novykova, V. I. (2009). Rekreatsiini posluhy: klasyfikatsiia ta rozvytok u Cherkaskii oblasti [Recreational services: classification and development in Cherkasy region]. Ukrainskyi heohrafichnyi zhurnal - Ukrainian Geographical Journal, 4. 33-39. [in Ukrainian].

5. World Tourism Organization. (2019). Sustainable Development. Retrieved from https://www.unwto.org/ru/node/79 [in English].

6. World Travel \& Tourism Council. (2019). Planning For Sustainable \& Inclusive Growth. Retrieved from https://wttc.org/Research/Insights/moduleId/1053/itemId/34/controller/DownloadRequest/action/QuickDownload [in English].

7. Ranieri, R., \& Ramos, R. A. (2013). Inclusive Growth: Building up a Concept. International Policy Centre for Inclusive Growth. Working Paper. Brazil.104. Retrieved from https://ipcig.org/pub/IPCWorkingPaper104.pdf [in English].

8. Tsymbaliuk, I. O. (2019). Inkliuzyvnyi rozvytok rehionu v umovakh finansovoi detsentralizatsii: teoriia, metodolohiia, praktyka: (monohrafiia) [Inclusive development of the region in terms of financial decentralization: theory, methodology, practice: (monograph)]. Lutsk. [in Ukrainian].

9. European Commission. (2010). Europe 2020. A European strategy for smart, sustainable and inclusive growth. Brussels. Retrieved from http://ec.eu-ropa.eu/europe2020/ index_en.htm [in English].

10. Bila, S. O. (2016). Stratehichni priorytety rozvytku turystychnykh posluh v Ukraini ta perspektyvy pidvyshchennia yikh konkurentospromozhnosti na svitovomu rynku [Strategic priorities of tourist services development in Ukraine and prospects of increasing their competitiveness on the world market]. Stratehiia rozvytku Ukrainy - Development strategy of Ukraine, 1. 1723. Retrieved from http://nbuv.gov.ua/UJRN/sru_2016_1_5 [in Ukrainian].

11. Cabinet of Ministers of Ukraine. (2017). Pro skhvalennia Stratehii rozvytku turyzmu ta kurortiv na period do 2026 roku: Rozporiadzhennia vid 16.03.2017 no 168-r [On approval of the Strategy for the development of tourism and resorts for the 
period up to 2026: Order dated 16.03.2017 № 168-r.]. Retrieved from https://zakon.rada.gov.ua/ laws/show/168-2017$\%$ D1\%80 [in Ukrainian].

12. Kovalova, O. V. (2019). Kontseptualni stratehichni priorytety rozroblennia strukturnoi polityky staloho rozvytku ahrarnoho sektoru ekonomiky: natsionalnyi i rehionalnyi aspekty [Conceptual strategic priorities of development of structural policy of sustainable development of agrarian sector of economy: national and regional aspects]. Visnyk Cherkaskoho universytetu Bulletin of Cherkasy University, 2. 66-76. [in Ukrainian].

13. Pavlikha, N. V., \& Skorokhod, I. S. (2005). Ekolohizatsiia turystychnoi sfery: innovatsiinyi pidkhid [Greening of the tourism sector: an innovative approach]. Visnyk DITB - DITB Bulletin, 9. 185-189. [in Ukrainian].

14. Khomiuk, N., \& Pavlikha, N. (2018). Economic security of development of rural territories in Ukraine. International Journal of New Economics and Social Sciences, 1 (7). 119-130. [in English].

15. Khomiuk, N. L. (2019). Dyversyfikatsiia rozvytku silskykh terytorii v umovakh detsentralizatsii (monohrafiia) [Rural Development Diversification in the Context of Decentralization]. Lutsk. [in Ukrainian].

Дата подання публікації 20.06.2020 p. 